\title{
Л. Даниленко
}

Київський національний університет імені Тараса Шевченка

м. Київ, Україна

Електронна пошта: dankoua@ukr.net

http://orcid.org/0000-0002-0252-8120

\section{Л. П. Дядечко}

Київський національний університет імені Тараса Шевченка

м. Київ, Україна

Електронна пошта: eptonim@ukr.net

http://orcid.org/0000-0002-7638-7163

\section{Danylenko}

Taras Shevchenko National University of Kyiv

Kyiv, Ukraine

E-mail: dankoua@ukr.net

http://orcid.org/0000-0002-0252-8120

\section{P. Diadechko}

Taras Shevchenko National University of Kyiv

Kyiv, Ukraine

E-mail: eptonim@ukr.net

http://orcid.org/0000-0002-7638-7163

\section{A MITE OF BIBLICAL WISDOM : A RUSSIAN-SLAVIC DICTIONARY OF WINGED EXPRESSIONS AND APHORISMS OF BIBLICAL ORIGIN, WITH GERMANIC, ROMANCE, ARMENIAN, AND GEORGIAN EQUIVALENTS / Ed. by E. E. Ivanov, V. M. Mokienko, D. Balakova, H. Walter. \\ Mogilev : Mogilev State A. Kuleshov Univ. Publ., 2019. Vol. 1. 288 p.; Vol. 2. 308 p.}

Дата надходження до редакції - 10.03.2020

Дата затвердження редакцією - 12.03.2020

DOI 10.33190/0027-2833-311-2020-2-006

Колесник В.

\section{ГОВІРКА БОЛГАР С. ГОРОДНЬОГО (ЧИЙШІЯ), БЕССАРАБІЯ : СЛОВНИК}

Одеса : Астропринт, 2019. 684 с. : іл.

Багатотомне видання «Болгарські говірки України» започаткували 1998 р. одеські мовознавці, дослідники болгарської діаспори в Болградському, Іванівському, Ізмаїльському, Тарутинському, Саратському та інших районах Одеської області - саме там проживає найбільша кількість нащадків болгар-переселенців, що розмовляють рідною мовою. Авторка цієї книжки, доктор філологічних наук В. Колесник опублікувала результати своїх лінгвістично-краєзнавчих експедицій і в попередніх томах - «Говірка болгар с. Кирнички, Бессарабія» (у співавторстві 3 3. Барболовою, 1998) та «Говірка с. Криничного (Чушмелій), Бессарабія» (2008). Рецензована праця присвячена мові болгар, що живуть у с. Городнє (Чийшія) Бол- 
градського району — це восьмий том із запланованих двадцяти.

«Говірка болгар с. Городнього (Чийшія), Бессарабія» двомовна - українсько-болгарська, до неї вміщено також розлогу анотацію англійською мовою. Теоретичні засади дослідження викладено українською, практичну частину написано болгарською, а точніше - унікальною переселенською говіркою, що здобула в болгарській лінгвістиці назву чийшійської, з фаховими коментарями літературною мовою.

Книжка складається 3 передмови, невеликої лінгвокраєзнавчої статті, власне словника досліджуваної говірки й містить чималі зразки текстів, записаних авторкою та ії асистентами-болгаристами в с. Чийшія від місцевих інформантів.

У передмові сказано кілька слів про історію заснування цього населеного пункту на початку XIX ст. болгарськими переселенцями. Дослідниця наголошує, що говірка, якою дотепер послуговуються болгари-чийшійці, належить до найцікавіших та найархаїчніших (с. 3). В. Колесник докладно розповідає про особливості організації досліджуваного матеріалу в цій книжці й наводить лаконічні та інформативні приклади-інструкції. Учена також окреслює подальші перспективи своїх мовознавчих студій - участь у створенні повного академічного словника болгарських говірок України (с. 4).

Стаття «Основні особливості чийшійської говірки» (с. 5-17) розширює й поглиблює краєзнавчу інформацію, наведену в передмові, про с. Чийшія, його географічну позицію, кількість населення та історію міграції болгар до Бессарабії, частиною якої була й Одещина. У мінімум тексту В. Колесник уміщує максимум відомостей про стан дослідження чийшійської говірки в болгаристиці. Мовознавиця аналізує специфіку болгарського діалектного мовлення на всіх можливих рівнях - фонетичному, морфемному, лексичному (с. 6-8), морфологічному (с. 9), висвітлює й деякі лінгвокультурні маркери болгарського ідіому в Одеській області (с. 12-13). Як і в попередніх працях, що належать до 20-томного проєкту, тут окреслено тенденції розвитку досліджуваної говірки в умовах іншомовного (українського, російського, молдавського) оточення (с. 15).

Саме в цій, першій частині книжки авторка висловлює головну ідею, спрямування своєї праці: «Наука про будь-яку мову, про її живу народну основу не може розвиватися і збагачуватися фактами без докладної характеристики говорів, особливо тих, які функціонують <...> в умовах переселенських анклавів різної величини й різного часу виникнення» (с. 16). Дослідження В. Колесник, за її власним переконанням, покликане стати істотним внеском до емпіричної бази української та болгарської діалектології, в чому читач пересвідчується, знайомлячись із лексикою, представленою в словниковій частині, та з автентичними болгарськими текстами.

Основна частина праці В. Колесник — «Чийшійська говірка. Словник» (с. 21653). Це реєстр найуживанішої лексики, яку дослідниця взяла безпосередньо зі спонтанного мовлення мешканців с. Городнього. Реєстрові слова подано не у фонетичній транскрипції, а в літературній болгарській транслітерації, що істотно полегшує роботу з лексикою при ії використанні як ілюстраційного матеріалу в лінгвістичних студіях. Однак укладачка не нехтує діалектними особливостями вимови, важливими для правильного прочитання слів: йáла, йела́, илá ‘іди, приходь’ при літературному ела́ (с. 223), манжеть 'манжета', літ. маншет (с. 320), ру́мна (ми) 'спасти на думку', літ. хрумна (с. 484). Інколи В. Колесник демонструє весь перелік діалектних форм, характерних для мови мешканців с. Городнього: тренда́фял, тринда́фял, трънда́фил, тренда́вил 'троянда' (с. 551).

Міждіалектна й міжмовна асиметрія не завжди дозволяють дібрати однозначний i точний відповідник до чийшійських екзотичних лексем. Більш ніж до половини реєстрових одиниць В. Колесник застосовує описовий переклад. Це зумовлено й необхідністю тлумачення деяких понять, переважно незнайомих сучасному читачеві навіть у болгарській метрополії: специфічний садівничий термін далдърмъ укладачка тлумачить болгарською як «далдърма, отведено и заровено в земята клонче за да пусне корен» («гілка, яку відігнули та прикопали, щоб вона пустила корінь»), а українською - як ‘кореневий відвід’ (с. 127), ла́вишняк у словнику пояснено як «черга за пейка і на стена, предназначена за постилане на лавици, по цвят най-често са черни с жълти и червени нишки 'ліжник, домоткана чорна шерстяна ковдра 3 жовтими та червоними смужками'» (с. 296), търли́ии «плитка домашна обувка» («пласке домашнє взутття») ‘повстяні тапки і плетені' (с. 562). 
В. Колесник намагається врахувати всі фонетичні, словотвірні й лексичні варіанти слів, які вживаються в городнянській говірці: абѐm (с. 22) та убя́m (с. 569) 'обід’, а́zне, а́zни (с. 23) і йѐгни (с. 223) 'ягня', абыкнав'ѐну (с. 22) та абы́чну (с. 23) 'зазвичай’, живо́т і жизня́ (с. 166) ‘життя', дро́жди (с. 148) та мая́ (с. 326) ‘дріжджі'. Легко запам'ятати різницю між значеннями омонімів гри́вна 'українська грошова одиниця, гривня’ та ‘браслет', оскільки, на відміну від літературної мови, у чийшійській говірці ці два слова вимовляють дещо по-різному (с. 114-115). У словнику відбиваються найрізноманітніші запозичення: українізми - бида́рка 'двоколісний віз’ (с. 49), бо́ндар (с. 56), сирни́к 'сірник' (с. 506), скърта 'копиця’ (с. 510), росіянізми - блин 'млинець' (с. 53), гаршо́к 'горщик' (с. 103), фка̀лувам ‘багато працювати' (c. 608), тюркізми - йеми́ш ‘солодощі' (с. 225), фили́з, ‘пагін' (с. 608), зокрема тюркізми арабського походження - аба́ 'груба валяна вовняна тканина' (c. 21), ферджѐ 'чоловічий довгий суконний верхній одяг — пальто' (с. 607) тощо.

У новій праці В. Колесник $є$ додаток - кілька кольорових глянцевих світлин iз зображенням згаданих у словнику специфічних реалій болгарської культури. Читачі, мало знайомі з болгарським традиційним побутом, мають можливість завдяки цим фото дізнатися про вигляд таких предметів, як чепра́зи, баре́зи, кюn, сто̀мна, ба́ска, чеврѐ, мано́фел, пешки́р, ла̀вичник.

Мети цього дослідження — відобразити лінгвоетнокультурну своєрідність українських болгар у синхронії й діахронії, — вчена, без сумніву, досягла. В. Колесник дбайливо фіксує в словникових статтях репліки інформантів, дотичні до реєстрових одиниць: ни́вга 'ніколи’ - ни́вга ни съ см’ей на свита Бугуродица «ніколи не смійся на день святої Богородиці» (с. 373), нѐшту 'щось'- Аку имаш душмани, знач'е нешту струваш «Якщо ти маєш ворогів, значить, ти чогось вартий» (с. 372), nъm 'дорога, шлях' - Койту първи намери дитету на път'а, става кръсн'ак «Хто перший знайде дитину на дорозі, той стане ії хрещеним» (с. 461), пуртъка́л 'апельсин' - Ала-бала пуртъкала «Тари-бари апельсин» (с. 452), ра̀бута ‘праця, заняття' - Нимала баба рабута, чи си купила прас'енци «Не мала баба клопоту, купила порося» (с. 465).

У праці В. Колесник значне місце відведено хрононімам - Масл'еница, Ма́слиница 'Масниці' (с. 205, 324), Тана́суфд'ен 'день святого Афанасія' (с. 289), Малкъ Кол 'адъ 'Мала Коляда; Коляда для дітей' (с. 318), Лусарската нид’ел'а 'Русальна неділя' (с. 308, 371), Тодурувден 'день вмч. Феодора Тирона' (с. 548). Словник фіксує чималу кількість назв, пов'язаних зі святковою обрядовістю - ма́ртеничка 'прикраси 3 кручених червоних та білих ниток, які приколюють на одяг 1 березня' (c. 322), пеперу́да 2. етн. Пеперуда 'весняне свято, обряд викликання дощу' (с. 396), núma 1. 'прісний хліб'; 2. 'народний звичай готувати та роздавати пuту, коли дитина починає ходити' (с. 403), про́шка 'відвідування молодими сватів після весілля' (c. 435), ри́бник 'пиріг з рибою (страва до свята Зимового Миколи. - О. М.)' (с. 477) тощо. Читач дізнається про те, що чийшійські болгари кличуть свиней гу́ц̧и-гу́uฺи (с. 123), а котів - маць-маџь (с. 325), що «равлик-павлик» зветься то̀ър-бодър (c. 548). Інформантки пояснюють, що русимй означає не лише росу, а й невинну, цнотливу дівчину (с. 684). У контексті дівочої цноти чийшійці старшого покоління згадують і напій медяна раке 'медова (солодка) горілка', якою молода частувала гостей після першої шлюбної ночі, якщо виявлялася «чесною» (с. 327).

Укладачка словника знайомить читачів з різноманітними ономасіологічними курйозами - наприклад, що означає калканюв ив'ет 'калкановий (камбаловий) колір' (с. 232), пувръштану дите 'букв. повторна, повернена дитина' (с. 442), фасул'ува шапка 'квасолева шапка' (с. 606). Трапляються у словнику й паремії: Присм'ал съ й дармон на раш'ету, чи му йедри дупкити «Сміялося решето з сита, що в того великі дірки» (с. 155); Кротку агни ут дв'е майки сучи «Покірливе ягня двох маток ссе» (с. 314); Раждала майка синув'е, да н'е й майлъть б'ез ората «Родила мати синів, щоб квартал не був безлюдним» (с. 315); Йад'е къту м'ечка, рабути къту бубул'ечка «Їсть як ведмідь, а працює як кузька» (с. 329); Млогу баби - на дит'ету пъn н'е й вързан «Багато повитух - у дитини пуповина не перев'язана» (c. 335); Вързън поп - мирну с'елу «Зв'язаний піп - спокійне село» (с. 414) та ін.

Остання частина книжки «Образци на текстове» («Зразки текстів») (с. 653-682) містить 20 розповідей з різних сфер народного життя болгар с. Городнього. Тут $€$ країнознавча розвідка про Чийшію, докладні описи технологій крою та шиття, тваринництва, кулінарії; місцеві жителі діляться з інтерв’юерами своїми знаннями з мі- 
фології, святкової та родинної ритуалістики, розповідають про дошлюбні та весільні звичаї й прикмети, що, безумовно, розширює й деталізує етномовну картину світу болгар-переселенців в уяві дослідників. Важливо також, що В. Колесник, добираючи тексти, дбає про представлення болгарської лінгвоетнокультури на мовному острові в ії динаміці, саме тому інформанти - представники різних поколінь, їм від 38 до 95 років.

Читачі мають змогу не лише дістати цікаві факти про традиційний болгарський побут, а й скласти уявлення про інтелектуальне багатство нащадків болгар-переселенців, надто старшого покоління. Так, добре структурована й інформаційно насичена усна розповідь Г. І. Іванової «Жънски дреи» («Жіночий одяг») справляє враження досконалого володіння науковим стилем, проте виявляється, що 94-річна городнянка закінчила лише чотири класи (с. 662-666). I хоча, за свідченням самої В. Колесник, у підготовці матеріалів допомагали вчителі місцевої школи (с. 4), але низка інших текстів засвідчує, що втручання фахівців-філологів у записані розповіді було мінімальним. Також заслуговує на увагу той факт, що згадки про минуле бережуть і вільно відтворюють молоді люди, які не застали ані тих звичаїв, ні пов'язаних із ними реалій. Так, корінна чийшійка 3. С. Курдоглова, якій на момент проведення інтерв'ю ще не виповнилося 40, добре знає, як у давні часи дівчина могла кілька годин стояти 3 парубком біля криниці, тримаючи коромисло $з$ повними відрами (с. 658). А вживання іншою молодою болгаркою дієслів у теперішньому часі, а не в минулому, при описі святкування Різдва - ód’zm ирг'е́ни «ходять парубки», жинйти късът пърч'е́нща ут сурва́чкътъ «жінки відривають шматочки від оздобленої на Різдво кизилової гілки (сурвачки)» (с. 659) переконливо свідчить про те, що найдавніші колядні звичаї, принесені з прабатьківщини, природні та популярні серед сучасної болгарської молоді, яка живе в Україні.

Праця В. Колесник орієнтована на широке коло читачів - як фахівців-болгаристів, так і тих, хто лише бажає ближче познайомитися з непересічним світом болгарського мовного острова на Півдні України. Для оформлення палітурки використано картину «Дух печі», автор якої, український болгарин, бессарабський та кримський художник Олександр Кара, відомий і в мистецьких колах метрополії. На цій картині - типовий болгарський сюжет, що одразу привертає увагу шанувальників жанрового живопису. Такий вибір ілюстрації красномовно свідчить про прагнення В. Колесник наголосити на безперервності етнокультурних традицій, привернути увагу аудиторії до вічних цінностей, серед яких - і рідна болгарська мова, успадкована від предків-мігрантів, а також продемонструвати потужну енергетику мови переселенців у позамовному просторі на теренах українського Півдня.

\title{
о. Малаш
}

Інститут мовознавства ім. О. О. Потебні НАН України, м. Київ, Україна

Електронна пошта: darmodej@ukr.net

http://orcid.org/0000-0002-5726-5646

\section{O. Malash}

O. O. Potebnia Institute of Linguistics of the National Academy of Sciences of Ukraine

Kyiv, Ukraine

E-mail: darmodej@ukr.net

http://orcid.org/0000-0002-5726-5646

\author{
Kolesnyk V. \\ (CHYISHIYA), BESSARABIA: A DICTIONARY \\ Odesa: Astroprint, 2019. 684 p. \\ Дата надходження до редакції - 16.03.2020 \\ Дата затвердження редакцією - 19.03.2020
}

THE DIALECT OF THE BULGARIANS OF THE VILLAGE OF HORODNIE

До уваги авторів: нові правила оформлення публікацій у журналі «Мовознавство» див. на сайті : https://movoznavstvo.org.ua/ 